\title{
An Eternal Promise? - Three Sketches on the Universality of International Humanitarian Law ${ }^{1}$
}

\author{
Tamás Hoffmann
}

\section{Introduction - The Dream of Universality}

Since time immemorial humankind has sought to create a regulatory framework that could mitigate the destruction of war. ${ }^{2}$ Ignatieff notes the ubiquity of military codes in all cultures and that "their common features are among the oldest artefacts of human morality"' 3 but the local diversity of such norms prevented the establishment of a generally applicable body of rules. By the $19^{\text {th }}$ century, however, the formation of standing armies, permanently organised national military forces that were solely vested with the sovereign monopoly of forces resulted in the progressive elimination of private modes of warfare and necessitated the development of a universal system of law of war. ${ }^{4}$ Since 1868 , states have concluded numerous international agreements codifying the laws of armed conflict and this field has become one of the most tightly regulated areas of international law. ${ }^{5}$ Moreover, many international lawyers emphasise that the very character of the law of armed conflict (LOAC) has undergone a profound transformation as signalled by the increasingly prevalent use of the ex-

1 This paper was written with the support of the Bolyai János Research Fellowship of the Hungarian Academy of Sciences and the Hungarian Scientific Research Fund OTKA (PD 113010). I would like to thank the editors, Enikő Dácz, Henriett Kovács and Christina Griessler for their - seemingly — endless patience in face of my - actually — never-ending delays of submitting the manuscript.

2 Harding emphasises that such rules are "as old an institution as war itself". Harding, Ian: The Origins and Effectiveness of the Geneva Conventions for the Protection of War Victims, in: International Review of the Red Cross, Vol. 13, 1973, No. 147, pp. 283-290, here p. 285.

3 Ignatieff, Michael: The Warrior's Honor: Ethnic War and the Modern Conscience, London: Chatto \& Windus, 1998, pp. 116-117.

4 Kennedy, David: War and International Law: Distinguishing Military and Humanitarian Professions, in: International Law Studies, Vol. 82, 2006, pp. 3-36, here p. 7.

5 For a full list of all international agreements see https://www.icrc.org/ihl (last accessed: 15 December 2014). 
pression "international humanitarian law" (IHL), a term that in itself implies universality and equal application to tame the horrors of armed conflict. ${ }^{6}$ In that vein, Meron explains that under the influence of human rights "the law of war has been changing and acquiring a more humane face: the inroads made on the dominant role of reciprocity; the fostering of accountability; the formation, formulation and interpretation of rules $[\ldots]^{\prime \prime 7}$

Such "humanized" humanitarian law seems to be the pinnacle of progress, the fulfilment of the ancient dream of humanity. Still, this pristine image is marred by a history of racism, exclusion, and lethal inclusion. In this paper I would like to reflect on these blemishes and examine whether international humanitarian law can move beyond its past and present to finally truly deserve such a lofty label.

\section{The Progress of Civilisation and Racism - Unity through Exclusion}

In 1868, on the proposition of Imperial Russia, the major world powers renounced for the first time in history in an international treaty the use of a particular means of warfare, explosive projectiles under the weight of 400 grammes. ${ }^{8}$ The preamble of the St. Petersburg Declaration enunciated that

6 Solis underlines that "the conflation of LOAC/IHL terminology reflects a desire of humanitarian-oriented groups and nongovernmental organisations to avoid phrases like "law of war" in favour of more pacific terms, perhaps in the hope that battlefield actions may someday follow that description." Solis, Gary D.: The Law of Armed Conflict: International Humanitarian Law in War, Cambridge: Cambridge University Press, 2010, p. 22. However, the term "international humanitarian law" is still not universally accepted as demonstrated by the US government's consistent use of the term "law of war" or "laws and customs of war" instead. See Bellinger, III, John. B/Haynes, II, William J.: A US Government Response to the International Committee of the Red Cross Study Customary International Humanitarian Law, in: International Review of the Red Cross, Vol. 89, 2007, No. 866, pp. 443-471, here p. 473. Moreover, many scholars still use the traditional term. See e.g. Byers, Michael: War Law: Understanding International Law and Armed Conflict, New York: Grove Press, 2005; Detter, Ingrid: The Law of War, $3^{\text {rd }}$ ed, London: Ashgate Press, 2013.

7 Meron, Theodor: The Humanization of International Law, Leiden: Martinus Nijhoff, 2006, p. 1.

81868 St. Petersburg Declaration Renouncing the Use, in Time of War, of Explosive Projectiles Under 400 Grammes Weight, opened for signature 11 December 1868 
there is an "expediency of forbidding the use of certain projectiles in times of war between civilised nations" and since "the only legitimate object which States should endeavour to accomplish during war is to weaken the military forces of the enemy" the employment of weapons which "uselessly aggravate the sufferings of disabled men, or render their death inevitable" should be prohibited. This pronouncement was couched in the general telos of progress as "the progress of civilisation should have the effect of alleviating as much as possible the calamities of war".

Three decades later, the preamble to the 1899 Hague Convention (II) asserted that:

Until a more complete code of the laws of war has been issued, the High Contracting Parties deem it expedient to declare that, in cases not included in the Regulations adopted by them, the inhabitants and the belligerents remain under the protection and the rule of the principles of the laws of nations, as they result from the usages established among civilised nations, from the laws of humanity, and the dictates of the public conscience. ${ }^{9}$

This formulation, widely known as "Martens Clause", named after the famous Russian jurist Fyodor Fyodorovich Martens, who suggested the inclusion of a general reference to unwritten principles to resolve a diplomatic deadlock during the negotiations, ${ }^{10}$ was restated in the preamble of the 1907 Hague Convention IV, which emphasised that it was paramount to "serve, even in this extreme case, the interest of humanity and the ever progressive needs of civilisation", ${ }^{11}$ while a slightly modified version appeared in Additional Protocol I to the 1949 Geneva Conventions, ${ }^{12}$ and it

(entry into force 11 December 1868). Roberts, Adam/Guelff, Richards: Documents on the Laws of War, Oxford: Oxford University Press, $3^{\text {rd }}$ ed., 2002, pp. 54-55.

9 Convention (II) with Respect to the Laws and Customs of War on Land and its Annex: Regulations concerning the Laws and Customs of War on Land, opened for signature 29 July 1899 (entry into force 4 September 1900). https://www.icrc.o $\mathrm{rg} /$ applic/ihl/ihl.nsf/Article.xsp?action=openDocument\&documentId=9FE084CD AC63D10FC12563CD00515C4D (last accessed: 13 December 2014).

10 See more in detail Cassese, Antonio: The Martens Clause: Half a Loaf or Simply Pie in the Sky? In: European Journal of International Law, Vol. 11, 2000, No. 1, pp.187-216, here pp. 193-198.

11 Convention (IV) Respecting the Laws and Customs of War on Land, opened for signature 18 October 1907 (entry into force 26 January 1910). Roberts/Guelff: Documents on the Laws of War, p. 69.

12 Art. 1 (2) declares that "[I]n cases not covered by this Protocol or by other international agreements, civilians and combatants remain under the protection and au- 
was incorporated into numerous other conventions regulating the means and methods of warfare. ${ }^{13}$ In its 1996 Advisory Opinion on the Legality of the Threat or Use of Nuclear Weapons (Nuclear Weapons Advisory Opinion) the International Court of Justice affirmed the relevance of the Martens Clause "whose continuing existence and applicability is not to be doubted" and declared that "it has proved to be an effective means of addressing the rapid evolution of military technology". ${ }^{14}$

Today the Martens Clause is generally regarded as a reminder that even in the absence of black letter law the belligerents' freedom to resort to violence in an armed conflict is constrained by customary law and general considerations of humanity. ${ }^{15}$ One could draw the conclusion from such references to progress, civilisation, and humanity that classical international law aimed at creating a universally applicable regulation of legitimate conduct during armed conflicts. After all, references to these noble ideals have predated the adoption of the 1868 St. Petersburg Declaration and we-

thority of the principles of international law derived from established custom, from the principles of humanity and from the dictates of public conscience." Protocol Additional to the Geneva Conventions of 12 August 1949, and relating to the Protection of Victims of International Armed Conflicts (Protocol I), opened for signature 8 June 1977, 1125 U.N.T.S 3 (entry into force 7 December 1979).

13 See inter alia, the reference to "the role of public conscience in furthering the principles of humanity" in the Convention on the Prohibition of the Use, Stockpiling, Production and Transfer of Anti-Personnel Mines and on Their Destruction (Ottawa Convention), opened for signature 18 September 1997, 2056 U.N.T.S 2041 (entry into force 1 March 1999); or the affirmation that "the rules governing the protection of cultural property in the event of armed conflict should reflect developments in international law", Second Protocol to the Hague Convention of 1954 for the Protection of Cultural Property in the Event of Armed Conflict, opened for signature 26 March 1999, 2253 U.N.T.S. 212 (entry into force 9 March 2004).

14 Legality of the Threat or Use of Nuclear Weapons, Advisory Opinion of 8 July 1996, I.C.J. Rep. 66, paras. 87. and 78. This reference was probably in part a reply to the extreme position submitted by Russia stating that "today the "Martens Clause' may formally be considered inapplicable". See Cassese: The Martens Clause, p. 211.

15 There is copious literature on the significance of the Martens Clause in international humanitarian law. See inter alia Ticehurst, Rupert: The Martens Clause and the Laws of Armed Conflict, in: International Review of the Red Cross, Vol. 37, 1997, No. 317, pp. 125-134.; Pustogarov, Vladimier Vasilievich: The Martens Clause in International Law, in: Journal of the History of International Law, Vol. 1, 1999, No. 1, pp. 125-135.; Meron, Theodor: The Martens Clause, Principles of Humanity, and Dictates of Public Conscience, in: American Journal of International Law, Vol. 94, 2000, No. 1, pp. 78-89. 
re used as justifications outside the scope of the law of war as well. The Declaration against the Slave Trade, signed at the Congress of Vienna in 1815, had already echoed this universalistic sentiment declaring that slave trade is "repugnant to the principles of humanity and universal morality [...] the public voice, in all civilised countries, calls aloud for its prompt suppression."'16

Notwithstanding the moral rhetoric and the frequent references to universal principles, the laws of nations were deemed to apply to "civilised" nations only, to countries that shared a similar, predominantly Western and Christian culture. Consequently, outside this scope international law did not (or only to a limited extent) regulate the relationship between "civilised" and "uncivilised" countries. ${ }^{17}$ A passage from Mill perfectly summarises this essentially racist justification of the differentiated application of international law. He argued that:

To suppose that the same international customs, and the same rules of international morality, can obtain between one civilised nation and another, and between civilised nations and barbarians, is a grave error, and one which no

16 Final Act of the Congress of Vienna, Act No. XV., Declaration of the Powers on the Abolition of the Slave Trade, signed on 8 February 1815. http:// en.wikisource.org/wiki/Final_Act_of_the_Congress_of_Vienna/Act_XV (last accessed: 20 December 2014). However, Grewe emphasises that reference to "mankind, humanity, civilisation, universal morals [...] was the vocabulary of English popular philosophy of the nineteenth century. It stood in stark contrast to the vocabulary of Vienna [...] to the evocation of the "esprit de fraternité" of the continental monarchs". Grewe, Wilhelm W.: The Epochs of International Law, Berlin; New York: de Gruyter, 2000, pp. 554-555. Similarly, Zagor points out that "[T] he characterization of an international legal rule as reflecting what would later in the Martens Clause be termed the 'dictates of public conscience' is as unique as it is disingenuous. The world society whose normative voice can be heard in the 1815 Declaration was essentially that of Britain, the emerging hegemon after the Napoleonic wars, where an organized and politicized public had demanded international action." Zagor, Matthew: Elementary Considerations of Humanity, in: Bannelier, Karine/Christakis, Theodore/Heathcote, Sarah (eds.): The ICJ and the Evolution of International Law: The Enduring Impact of the "Corfu Channel" Case, Oxon: Routledge, 2011, pp. 264-291, here p. 270.

17 On the standard of civilisation see Gong, Gerrit W.: The Standard of Civilization, Oxford: Oxford University Press, 1984. Alexandrowicz argues that before the $19^{\text {th }}$ century relations between European and non-European powers were more equal and the emergence of positivistic jurisprudence caused a discernible shift. See Alexandrowicz, Charles Henry: Doctrinal Aspects of the Universality of the Law of Nations, in: British Yearbook of International Law, Vol. 37, 1961, pp. 506-515. 
statesman can fall into however it may be with those, who from a safe and unresponsable position, criticise statesmen. Among the many reasons why the same rules cannot be applicable to situations so different, the two following are among the most important. In the first place, the rules of ordinary international morality imply reciprocity. But barbarians will not reciprocate. They cannot be depended on for observing any rules. Their minds are not capable of so great an effort, nor their will sufficiently under the influence of distant motives. In the next place, nations which are still barbarous have not got beyond the period during which it is likely to be for their benefit that they should be conquered and held in subjection by foreigners [...] To characterise any conduct whatever towards a barbarous people as a violation of the law of nations, only shows that he who so speaks has never considered the subject. A violation of great principles of morality it may easily be, but barbarians have no rights as a nation, except a right to such treatment as may, at the earliest possible period, fit them for becoming one. The only moral laws for the relation between a civilised and a barbarous government are the universal rules of morality between man and man. ${ }^{18}$

For contemporary authors, the "non-civilised", barbarous", "savage" people were biologically incapable of complying with the normative regulation of international law. They could not be placed on an equal footing with the European, civilised world but had to be controlled and civilised - forcefully, if necessary. Inevitably, they did not possess sovereignty unless to the limited extent that they had the right to transfer ownership of their land to the colonising powers. ${ }^{19}$ As put pithily by Anghie: "[T]he ba-

18 Mill, John Stuart: A Few Words on Non-intervention, in: Mill, John Stuart: Dissertations and Discussions: Political, Philosophical, and Historical, Boston: William V. Spencer, 1867, Vol. 4, pp. 157-182, here pp. 171-172. A century earlier Hume similarly contended that: "There was never a civilised nation of any other complexion than white, nor even any individual eminent either in action or speculation. No ingenious manufactures amongst them, no arts, no sciences. On the other hand, the most rude and barbarous of the whites, such as the ancient Germans, the present Tartars, have still something eminent about them, in their valour, form of government, or some other particular. Such a uniform and constant difference could not happen, in so many countries and ages, if nature had not made an original distinction betwixt these breeds of men." Hume, David: Of National Characters, in: Hume, David: Essays and Treatises on Several Subjects, London: A. Millar, 1760, Vol. 1, pp. 321-348, here p. 337.

19 Lorimer for instance emphasised that the international lawyer "is not bound to apply the positive law of nations to savages, or even to barbarians, as such; but he is bound to ascertain the points at which, and the directions in which, barbarians or savages come within the scope of partial recognition." Lorimer, James: The Institutes of the Law of Nations: A Treatise of the Jural Relations of Separate Political Communities, Edinburgh: William Blackwood and Sons, 1883, Vol. I, p. 102. 
sic point is that the development of the idea of sovereignty in relation to the non-European world occurs in terms of dispossession, its ability to alienate its lands and rights $[. .$.$] the native is granted personality in order$ to be bound". ${ }^{20}$ This meant that such sovereignty was "only tenuously connected with its own identity; rather, it was artificially created in accordance with the interests and world view of Europe; it emerged from and was inextricably linked with complex of practices which were explicitly directed towards the exploitation and domination of non-European peoples". ${ }^{21}$

To rationalize mission civilisatrice as a standard justification for colonization, ${ }^{22}$ contemporary scholarship had to resort to biological and anthropological arguments. Analysing the works of Cambridge law professor Thomas J. Lawrence, Riles observes that texts are replete with references to the crude biological nature of the "race of savages" and the "dwarfs of the Central African forest," for example. The thrill of the racialized savage - the thrill of racism - is the thrill of catagorizing, of ordering, of controlling; and Lawrence's use of this imagery in his treatise imputed this thrill to international law $[\ldots]^{23}$

The savage was regarded subhuman and superhuman at the same time, which warranted the non-application of the law of war. The savage was subhuman since he was driven by his violent nature that resulted in a constant state of war and all kinds of moral depravities. Lawrence thus argued that:

20 Anghie, Anthony: Imperialism, Sovereignty and the Making of International Law, Cambridge: Cambridge University Press, 2004, p. 105.

21 Anghie: Imperialism, Sovereignty and the Making of International Law, p. 104.

22 In the opening speech of the 1884-85 Africa Conference for instance Prince Bismarck noted that "all the Governments invited share the wish to bring the natives of Africa within the pale of civilization by opening up the interior of the continent to commerce [...]" See Anghie: Imperialism, Sovereignty and the Making of International Law, p. 97. Orford insightfully remarks that "[T]he hero's journey is about civilisation, progress or development of that colonised subject. Intervention by white men is justified in order first to civilise the natives of subject colonies, and later, in the era of decolonisation, to assist the development of those former colonies. The notion of progress continues to provide the imaginative framework for intervention stories in the era of decolonisation." See Orford, Anne: Reading Humanitarian Intervention: Human Rights and the Use of Force in International Law, Cambridge: Cambridge University Press, 2003, p. 171.

23 Riles, Annelise: Aspiration and Control: International Legal Rhetoric and the Essentialization of Culture, in: Harvard Law Review, Vol. 106, 1993, pp. 723-740, here p. 729 . 
War between savage tribes is marked by the unrestricted indulgence of man's fiercest passions. Conquered enemies are enslaved, or tortured, or even eaten. Whatever hatred suggests is done without stint or limit. The actual fighting is carried on in the most ferocious and bloodthirsty manner, and when it is over the vanquished are made to drain the cup of misery to the last bitter drop $[\ldots]^{\prime 24}$

At the same time, the savage apparently had a superhuman physical strength and stamina so the usual restrictions of the law of war concerning means and methods of warfare could not possibly affect colonial warfare. In a revealing episode, Great Britain supported the ban of expanding (dum-dum) bullets at the 1899 Hague Conference but made a case for an exception in colonial conflicts. The British representative, Sir John Ardagh scornfully argued that:

In civilised war a soldier penetrated by a small projectile is wounded, withdraws to the ambulance, and does not advance any further. It is very different with a savage. Even though pierced two or three times, he does not cease to march forward, does not call upon the hospital attendants, but continues on, and before anyone has time to explain to him that he is flagrantly violating the decision of the Hague Conference, he cuts off your head. ${ }^{25}$

While the British proposition was ultimately defeated, the underlying idea that since the savages are incapable of showing restraint in warfare the law of war cannot apply to them persisted. ${ }^{26}$ Indeed, according to a widely held view the only humane course of action in such situations was the un-

24 Thomas J. Lawrence, The Evolution of Peace, in: Essays on Some Disputed Questions of International Law, Cambridge: Deighton, Bell and Co., 1884, pp. 214252, here p. 236.

25 Scott, James B., The Hague Peace Conferences of 1899 and 1907, Baltimore: Johns Hopkins Press, 1909, Vol. I., p. 343.

26 Moreover, since non-Western peoples were not accepted as civilised nations, they could not participate in international legislation either. Among the signatories of the 1868 St. Petersburg Declaration, there was only two non-Western states, Persia and Turkey. At the 1899 Hague Peace Conference this paltry number only grew marginally by the presence of Japan and Siam. Mégret aptly points out that "The perversity of this whole situation is, of course, that the nonparticipation of 'noncivilized nations' in humanitarian treaties was not their choice, but simply a consequence of the fact that, since they were not considered sovereign (a quality from which they were excluded by 'civilized nations'), they could not possibly join these treaties." Mégret, Frédéric: From 'Savages' to Unlawful Combatants: a Postcolonial Look at International Humanitarian Law's 'Other', in: Orford, Anne (ed.): International Law and Its Others, Cambridge: Cambridge University Press, 2006, pp. 265-317, here p. 285 
restrained use of violence. Treitschke supported the excesses of the German colonial warfare since "international law becomes phrases if its standards are also applied to barbaric peoples. To punish a Negro tribe, villages must be burned [...] If the German Reich in such cases applied international law, it would not be humanity or justice but shameful weakness."27 Similarly, Colby held that

[I]f a few "non-combatants" - if there be any such in native folk of this character - are killed, the loss of life is probably far less than might have been sustained in prolonged operations of a more polite character. The inhuman act thus becomes actually humane, for it shortens the conflict and prevents the shedding of more excessive quantities of blood. ${ }^{28}$

According to this view, while the dictates of human decency and the requirement of maintaining military discipline could still result in the enforcement of some rules of the law of armed conflict, ${ }^{29}$ ultimately it was within the discretion of the military commanders to determine which norms they wished to adhere to. ${ }^{30}$

The idea of Western superiority has lost all intellectual currency by the end of World War II and Article 1 (3) of the Charter of the United Nations explicitly prescribed "promoting and encouraging respect for human rights and for fundamental freedoms for all without distinction as to race, sex,

27 Lindovist, Sven: "Exterminate All the Brutes": One Man's Odyssey into the Heart of Darkness and the Origins of European Genocide, New York: New Press, 1992, p. 157.

28 Colby, Eldridge: How to Fight Savage Tribes, in: American Journal of International Law, Vol. 21, 1927, No. 2, pp. 279-288, here p. 287. See however the article of Wright arguing for a limited application of international law in such situations. Wright, Quincy: The Bombardment of Damascus, in: American Journal of International Law, Vol. 20, 1926, No. 2, pp. 263-280.

29 See Colby: How to Fight Savage Tribes, pp. 286-287.

30 See also the directive issued by Royal Air Force Chief of the Air Staff, Hugh Trenchard, on 1 March 1924 that highlighted that "[I]n warfare against savage tribes who do not conform to codes of civilized warfare, air bombardment is not necessarily limited in its methods or objectives by rules agreed upon in international law." See Trenchard, Hugh: Employment of Aircraft on the North-West Frontier of India, Royal Air Force Directive issued on 1 March 1924, cited in Chandler, Graham: The Bombing of Waziristan, in: Air and Space Magazine, July 2011, http://www.airspacemag.com/military-aviation/the-bombing-of-waziristan-1 62104725/ (last accessed: 4 January 2015). 
language, or religion" as one of the purposes of the United Nations. ${ }^{31}$ The savage may have no longer "provided the symbolic counterpoint to $[\ldots]$ [the] ordering functions of international law' ${ }^{32}$ but the universal application of the law of armed conflict was still not accomplished.

Lack of Universality - The Distinction between International and NonInternational Armed Conflicts

\section{The Regulation of Insurgency and Belligerency}

Before the Second World War, international law focused on the regulation of inter-state violence and consequently generally regarded civil wars as falling into the domaine réservé of sovereign states. Classical international law literature used a spate of different expressions to denote internal conflicts, inter alia riot, mob violence, insurrection, disturbances, rebellion, commotion etc. The legal significance of this differing terminology, however, seemed to be uncertain at best. ${ }^{33}$ The rules of the laws of armed conflict only became applicable when the state accorded recognition of insurgency or belligerency to the rebels, accepting them as equal belligerents. The doctrine of belligerent recognition took shape in the early nineteenth century through a practice arising from the conflict in the Spanish-American colonies. The first recognition of belligerency occurred in 1815 when the United States granted belligerent rights to the South American states still fighting for their independence against Spain and Great Britain followed suit in $1819 .{ }^{34}$

31 Charter of the United Nations, opened for signature 26 June 1945, 1 U.N.T.S. 16 (entry into force 24 October 1945). Although the vestiges of the idea of distinction between civilised and non-civilised nations remained in the Statute of the International Court of Justice with the reference to "general principles of law recognised by civilised nations" as a source of international law in Art. 38 (1) (c). Statute of the International Court of Justice, opened for signature 26 June 1945, 33 U.N.T.S. 993 (entry into force 24 October 1945).

32 Riles: Aspiration and Control, p. 730.

33 For an excellent overview of the relevant English, French and German terminology see Lombardi, Aldo Virgilio: Bürgerkrieg und Völkerrecht, Berlin: Dunckler \& Humblot, 1976, pp. 75-85.

34 Moir, Lindsay: The Law of Internal Armed Conflict, Cambridge: Cambridge University Press, 2002, pp. 6-7. 
The main difference between insurgency and belligerency was the scope of corresponding rights. While insurgency was merely a provisional classification, which would arise merely to settle problems arising from de facto control of territory by rebels, ${ }^{35}$ recognition of belligerency created a formal status involving rights and duties, since each of the parties had the right to exercise belligerent rights such as search of ships on the high seas, seizure of contraband and confiscation of ships running and effective blockade. ${ }^{36}$ Moreover, by recognising the rebels as belligerents, the government was putting them "under an obligation to respect the customs of war against its own forces, and at the same time freeing itself from any responsibility for acts committed by the recognised belligerents". ${ }^{37}$ Even though recognition of belligerency was claimed to be based on facts, ${ }^{38}$ the distinction between insurgency and belligerency was still uncertain. Legal opinion varied about the consequences of the recognition of insurgency and about the necessity of the recognition of belligerency to bring about the application of the full gamut of the laws of war..$^{39}$

In theory, recognition of belligerency was obligatory in case the conditions were fulfilled, however, in reality "the imprecision of the criteria left

35 Green defined insurgency as "a condition or status in which organized bodies of men are in a state of armed hostility against the established government for public political purposes. It is something more than mere riot. Insurgency status is attained when the insurgent movement has become an actual threat to the continuation of the established government and succeeded in interrupting normal foreign intercourse between the legitimate government and foreign states." See Green, Fred K.: The Concept of "War" and the Concept of "Combatant" in Modern Conflicts, in: Military Law and Law of War Review, Vol. 10, 1971, pp. 267-309, here p. 270.

36 Shaw, Malcolm N.: International Law, Cambridge: Cambridge University Press, $2008,6^{\text {th }}$ ed., p. 149.

37 De la Haye, Eve: War Crimes in Internal Armed Conflicts, Cambridge: Cambridge University Press, 2008, p. 35.

38 During the 1867 Cretan Insurrection British Law Officers stated that "[I]t is always a question of fact to be determined by the Government of the Neutral State, whether the Insurrection has or has not assumed the dimensions of War, and whether the legitimate interests of the Neutral State do or do not require that she should claim from both parties to the performance towards her of the obligations incident to the Status of a belligerent." Quoted in Moir: The Law of Internal Armed Conflict, pp. 14-15.

39 For a masterful discussion of the issue see Wright, Quincy: The American Civil War, in: Falk, Richard A. (ed.) The International Law of Civil War, Baltimore and London: The Johns Hopkins Press, 1971, pp. 30-110, here pp. 42-54. 
the legal government discretion to decide whether or not to recognise the existence of conflict." ${ }^{\prime 40}$ At the end of the day, recognition of belligerency was a decision largely based on policy considerations, ${ }^{41}$ such as the desire to escape responsibility for the acts of the insurgents or, in the interests of humanity, to avoid cruelties and reprisals ${ }^{42}$ and the perceived lack of effectiveness of insurgents was regularly invoked as a convenient justification for refusal to accord belligerent status. ${ }^{43}$

\section{The Distinction between International and Non-International Armed Conflicts}

After 1945, due to the desuetude of the regime of recognition of belligerency and drawing on the horrors of the Spanish Civil War, the inevitability of the regulation of internal hostilities became evident. To remedy this gap in legal regulation, Common Article 3 to the Geneva Conventions was adopted as a revolutionary new piece of international legislation. ${ }^{44}$ The Article represents an uneasy compromise between the humanitarians seeking to extend the full body of international humanitarian law to internal conflicts and those attempting to preserve the sovereign rights of states..$^{45}$ It appears with identical text in all four of the Geneva Conventi-

40 Zorgbibe, Charles: Sources of the Recognition of Belligerent Status, in: International Review of the Red Cross, Vol. 17, 1977, No. 192, pp. 111-127, here p. 113.

41 Wilson, Robert R.: Recognition of Insurgency and Belligerency, in: American Society of International Law Proceedings, Vol. 31, 1937, pp. 136-144, here p. 138.

42 Wilson: Recognition of Insurgency and Belligerency, p. 139. See the Williams v. Bruffy case, where the US Supreme Court explained that recognition of belligerency and concession of the exercise of belligerents' rights by the insurgents "is made in the interest of humanity, to prevent the cruelties which would inevitably follow mutual reprisals and retaliations.” Williams v. Bruffy (1877), 96 US 176, p. 186.

43 Accordingly, French president Stourm justified denying recognition of belligerent status of the 1864 Polish insurrection by pointing out that the Polish forces did not have a de facto government, did not control territory, and did not have responsible command. See Zorgbibe: Sources of the Recognition of Belligerent Status, pp. 121-122.

44 See Moir: The Law of Internal Armed Conflict, pp. 23-29.

45 Georges Abi-Saab, 'Non-international Armed Conflicts', in: Jiri Toman (ed.) International Dimensions of Humanitarian Law, 1988, Dordrecht: Martinus Nijhoff Publishers, pp. 217-239, here pp. 218-221. 
ons and constitutes a completely separate entity from the other provisions, a "Convention in miniature". 46

Even though its text contains only a series of rudimentary provisions dealing with minimum rights and obligations in case of an "armed conflict not of an international character", ${ }^{47}$ it was hailed by the International Court of Justice as the expression of "elementary considerations of humanity", which are applicable in all armed conflicts. ${ }^{48}$ However, the definition of "armed conflict not of an international character" is conspicuously missing from the text. ${ }^{49}$

46 Pictet, Jean (ed.) Convention (IV) relative to the Protection of Civilian Persons in Time of War, Geneva: International Committee of the Red Cross, 1958, p. 34.

47 Common Article 3 reads: "In the case of armed conflict not of an international character occurring in the territory of one of the High Contracting Parties, each Party to the conflict shall be bound to apply, as a minimum, the following provisions:

(1) Persons taking no active part in the hostilities, including members of armed forces who have laid down their arms and those placed hors de combat by sickness, wounds, detention, or any other cause, shall in all circumstances be treated humanely, without any adverse distinction founded on race, colour, religion or faith, sex, birth or wealth, or any other similar criteria.

To this end the following acts are and shall remain prohibited at any time and in any place whatsoever with respect to the above-mentioned persons:

(a) violence to life and person, in particular murder of all kinds, mutilation, cruel treatment and torture;

(b) taking of hostages;

(c) outrages upon personal dignity, in particular humiliating and degrading treatment;

(d) the passing of sentences and the carrying out of executions without previous judgment pronounced by a regularly constituted court, affording all the judicial guarantees which are recognized as indispensable by civilized peoples.

(2) The wounded and sick shall be collected and cared for.

An impartial humanitarian body, such as the International Committee of the Red Cross, may offer its services to the Parties to the conflict.

The Parties to the conflict should further endeavour to bring into force, by means of special agreements, all or part of the other provisions of the present Convention. The application of the preceding provisions shall not affect the legal status of the Parties to the conflict." See https://www.icrc.org/ihl/WebART/375-590006 (last accessed: 8 April 2015.).

48 Military and Paramilitary Activities in and against Nicaragua, (Nicaragua v. United States), Merits, ICJ Reports, 1986, paragraph 218.

49 The ICRC Commentary finds this omission a positive attribute as it enables a wider scope of application. Pictet (ed.): Convention (IV), p. 36. Draper, however, notes that this leaves the provision "open to much ambiguity of interpretation. As 
A few years after the adoption of the 1949 Geneva Convention, Pictet submitted that Common Article 3 should have an extremely wide scope of application, extending it to virtually every single instance of violence by appealing to humanitarian considerations. ${ }^{50}$ However, the travaux préparatoires reveal that during the 1949 Diplomatic Conference, most states wished to set a very high threshold of application for Common Article 3. The US delegation, for instance, emphasised that insurgents must possess a state-like structure, similar to the classic conditions of recognition of belligerency. ${ }^{51}$ Correspondingly, the Australian ${ }^{52}$ and Canadian ${ }^{53}$ delegations submitted similar proposals. ${ }^{54}$ It can be concluded that the drafters conceived the term "armed conflict not of an international character" to refer to "situations of civil war, i.e. non-international armed conflict reaching the threshold of intensity associated with contemporaneous conventional international warfare." ${ }^{55}$ In practice, states usually denied the existence of a non-international armed conflict, even in exceptionally serious internal conflicts, to avoid conferring a legitimate status to rebels. During the 1954-1962 Algerian War of Independence, France never officially recognised that the "rebellion" had reached the threshold of an armed conflict and treated the conflict as a law-enforcement situation ${ }^{56}$ even

is so often the case with humanitarian law instruments, this is the outcome of the desire for maximum width for the play of the humanitarian norms, overriding the desire for that element of certainty which legal norms demand if they are to be effective." Dare Draper, Gerald Irving A.: Humanitarian Law and Internal Armed Conflicts, in: Georgia Journal of International and Comparative Law, Vol. 13, 1983, pp. 253-257, here p. 264.

50 Pictet (ed.), Convention (IV), p. 36.

51 The US Head of Delegation, Leland Harrison, underlined that "the insurgents must have an organization purporting to have the characteristics of a State"; must possess control over a defined territory and persons; rebel armed forces must have responsible command and comply with humanitarian law; and finally the insurgent civil authority must expressly accept the obligations of the Conventions. Final Record, Vol. II-B, Summary Records, 2 ${ }^{\text {nd }}$ Meeting, p. 12.

52 Final Record, Vol. II-B, Summary Records, $2^{\text {nd }}$ Meeting, p. 15.

53 Ibid., p. 13.

54 For a thorough perusal of the travaux préparatoires see Cullen, Anthony: The Concept of Non-International Armed Conflict in International Humanitarian Law, Cambridge: Cambridge University Press, 2010, pp. 27-49.

55 Cullen: The Concept of Non-International Armed Conflict, p. 37.

56 Katherine Draper describes how "the French government employed an impressive variety of creative legal semantics to avoid officially recognizing the conflict as a “war."” Draper, Katherine: Why a War Without a Name May Need One: Policy- 
though it had to deploy substantial military forces against the Front de Libération Nationale. ${ }^{57}$

This consistent practice of non-recognition of the existence of an armed conflict in colonial wars has effectively recreated the former - allegedly abolished differentiation concerning conflicts between civilised and noncivilised people. Yet, it must be admitted that the newly independent former colonies were quite glad to maintain the dichotomy between international and non-international armed conflicts and certainly not too eager to extend the protection of international humanitarian law to insurgents fighting against their rule.

By the 1990s the conventional framework of international humanitarian law only gave a skeletal regulation of non-international armed conflicts ${ }^{58}$ and the existence of any customary rules pertaining to the regulation of means and methods of warfare beyond the scope of treaty provisions was generally denied. ${ }^{59}$ In 1995, however, the International Criminal Tribunal for the Former Yugoslavia (ICTY) issued a ground-breaking judgment which stated that there exists a wide range of customary norms applicable to non-international armed conflicts and defined the scope of application

Based Application of International Humanitarian Law in the Algerian War, in: Texas International Law Journal, Vol. 48, 2013, No. 3, pp. 575-602, here p. 585. However, in 1956 the French Prime Minister accepted an offer by the International Committee of the Red Cross to visit prisoners "in conformity with Article 3 of the Geneva Conventions regarding armed conflicts not of an international character" and thus implicitly accepted that the conflict amounted to a non-international armed conflict. See Flory, Maurice: Algérie et Droit International, in: Annuaire Français de Droit International, Vol. 5, 1959, pp. 817-844, here p. 831.

57 See more in detail Greenberg, Eldon van Cleef: Law and the Conduct of the Algerian Revolution, in: Harvard Journal of International Law, Vol. 11, 1970, pp. 37 72.

58 Greenwood, Christopher: Development of International Humanitarian Law by the International Criminal Tribunal for the Former Yugoslavia, in: Max Planck Yearbook of United Nations Law, Vol. 2, 1998, pp. 97-140, here p. 128.

59 See e.g. Farer, Thomas: Humanitarian Law and Armed Conflicts: Toward the Definition of "International Armed Conflict", in: Columbia Law Review, Vol. 71, 1971, pp. 37-72., here p. 40; Bond, James E.: Application of the Law of War to Internal Conflicts, in: Georgia Journal of International Law, Vol. 3, 1973, pp. 345 384; Eitel, Tono: Lebanon - A Legal Survey, in: (1986) 29 German Yearbook of International Law, Vol. 29, 1986, pp. 11-55, here p. 19. But see Fischer, Horst: Limitation and Prohibition of the Use of Certain Weapons in Non-International Armed Conflicts, in: Yearbook of the International Institute of Humanitarian Law, 1989, pp. 117-180. 
of these rights. In the Tadic jurisdiction case the Appeals Chamber submitted that "an armed conflict exists whenever there is [...] protracted armed violence between governmental authorities and organised armed groups or between such groups within a State". ${ }^{60}$ This definition has generally been accepted as a restatement of customary international law, consistently reiterated by the ICTY, ${ }^{61}$ the International Criminal Tribunal for Rwanda, ${ }^{62}$ the International Criminal Court, ${ }^{63}$ internationalised criminal courts, ${ }^{64}$ military law manuals ${ }^{65}$ and international expert reports. ${ }^{66}$ The cu-

60 Prosecutor v Tadić (Decision on the Defence Motion for Interlocutory Appeal on Jurisdiction) (International Criminal Tribunal for the Former Yugoslavia, Appeals Chamber, Case No IT-94-1-AR72, 2 October 1995) [70].

61 See inter alia Prosecutor v Delalić et al. (Judgement) (International Criminal Tribunal for the Former Yugoslavia, Trial Chamber II, Case No IT-96-21-T, 16 November 1998) [183]; Prosecutor v Kordić and Čerkez (Judgement) (International Criminal Tribunal for the Former Yugoslavia, Trial Chamber I, Case No IT-95-14/2-T, 26 February 2001) [24]; Prosecutor v Kunarac et al (Judgement) (International Criminal Tribunal for the Former Yugoslavia, Appeals Chamber, Case No IT-96-23\&IT-96-23/1-A, 12 June 2002) [56]; Prosecutor v. Milutinović et al (Judgement) (International Criminal Tribunal for the Former Yugoslavia, Trial Chamber I, Case No IT-05-87-T, 26 February 2009) [125]; Prosecutor v. Gotovina et al (Judgement) (International Criminal Tribunal for the Former Yugoslavia, Trial Chamber I, Case No IT-06-90-T, 15 April 2011) [1674].

62 Prosecutor v. Akayesu (Judgement) (International Criminal Tribunal for Rwanda, Trial Chamber I, Case No ICTR-96-4-T, 2 September 1998) [619]; Prosecutor v. Rutaganda, (Judgement) (International Criminal Tribunal for Rwanda, Trial Chamber I, Case No ICTR-96-3-T, 6 December 1999) [92].

63 Prosecutor v. Lubanga (Decision on the Confirmation of Charges) (International Criminal Court, Pre-Trial Chamber I, Case No ICC-01/04-01/06, 29 January 2007) [233].

64 Prosecutor v. Eav (Judgement) (Extraordinary Chambers in the Courts of Cambodia, Trial Chamber, Case No. 001/18-07-2007/ECCC/TC, 26 July 2010) ('Eav Trial') [412].

65 UK Ministry of Defence: Manual of the Law of Armed Conflict, Oxford: Oxford University Press, 2004, p. 29.; Dinstein, Yoram/Garraway, Charles H.B./Schmitt, Michael N. (eds.) The Manual on the Law of Non-International Armed Conflict with Commentary, San Remo: San Remo Institute of International Humanitarian Law, 2006, p. 2.

66 International Commission of Inquiry on Darfur, Report to the United Nations Secretary-General pursuant to Security Council Resolution 1564 of 18 September 2004, UN Doc. S/2005/60 (25 January 2005) [74]; Commission of Inquiry on Lebanon, Report pursuant to Human Rights Council Resolution S-2/1, UN Doc. A/HRC/3/2 (23 November 2006) [51]; International Commission of Inquiry, Re- 
stomary status of the Tadić definition is also buttressed by its inclusion in Article 8 (2) (f) of the Rome Statute of the International Criminal Court. ${ }^{67}$

While this decision arguably amounted to judicial law-making, today it is generally accepted that the majority of the norms applicable to international armed conflicts now also extend to non-international armed conflicts. ${ }^{68}$ Judge Cassese summarized this phenomenon the following way:

$[\mathrm{T}]$ here has been a convergence of two bodies of international law with the result that internal strife is now governed to a large extent by the rules and principles which had traditionally only applied to international conflicts. [...] regarding the formation of customary international law rules to protect those who are not taking part in hostilities, $[\ldots]$ this convergence has come about due largely to the following factors: (1) the increase in the number of civil conflicts; (2) the increase in the level of cruelty of internal conflicts; (3) the increasing interdependence of States; (4) the influence of universal human rights standards. The Appeals Chamber then turned to the extension of the rules regarding methods and means of warfare to internal armed conflicts and concluded that a similar blurring had occurred. In short, certain norms apply as customary international law to internal and international conflicts alike. ${ }^{69}$

This remarkable transformation of international humanitarian law is aptly demonstrated by the Customary Law Study of the International Committee of the Red Cross (ICRC). ${ }^{70}$ The ICRC Study attempts to authoritatively identify the customary norms of humanitarian law and found that most rules of international humanitarian law are now equally applicable in inter-

port on Alleged Violations of International Human Rights Law in the Libyan Arab Jamahiriya, A/HRC/17/44 (1 June 2011) [63].

67 Article 8 (2) (f) provides that "Paragraph 2 (e) applies to armed conflicts not of an international character [...] that take place in the territory of a State when there is protracted armed conflict between governmental authorities and organized armed groups or between such groups." Rome Statute of the International Criminal Court, opened for signature 17 July 1988, 2187 UNTS 90 (entered into force 1 July 2002).

68 See more in detail Hoffmann, Tamás: The Gentle Humanizer of Humanitarian Law - Antonio Cassese and the Creation of the Customary Law of Non-international Armed Conflict, in: Stahn, Carsten/Herik, Larissa van den (eds): Future Perspectives on International Criminal Justice, The Hague: TMC Asser, 2010, pp. 5880.

69 United Nations Memorandum from President Cassese to Members of the Preparatory Committee on the Establishment of an International Criminal Court on the Definition of War Crimes and General Principles of Criminal Law as Reflected in the International Tribunal's Jurisprudence, 22 March 1996, paragraph 11.

70 Henckaerts, Jean-Marie/Doswald-Beck, Louise (eds.): Customary International Humanitarian Law, Cambridge: Cambridge University Press, 2005, Vol. I-II. 
national and non-international armed conflicts alike. ${ }^{71}$ Still, even though there have been suggestions for eliminating this dichotomy, ${ }^{72}$ a complete unification of the two fields seems to be unrealistic. Some rules pertaining to international conflict would be ill-fit to a non-international armed conflict. It is obvious that the rules of occupation cannot be completely applied to civil wars as the regulation of occupation is based on the notion of temporary administration of a territory without the infringements of sovereign rights. It is difficult to imagine how that could be applied in its entirety to an internal conflict, for instance the injunctions against changing existing laws or the dismissal of members of the public administration.

Still, some countries have effectively abolished the distinction between different legal regimes on the ground. For instance, the armed forces of the United States ${ }^{73}$ and Germany ${ }^{74}$ apply the rules of international humanitarian law irrespective of the type of conflict. Similarly, the Canadian Armed Forces apply in such manner the "spirit and principles" of humanitarian law. ${ }^{75}$ Yet, while this regulation reflects policy considerations to ensure the respect of international humanitarian law to the fullest possible extent, these countries still maintain the traditional dichotomy with regard

71 The Study heavily draws on the jurisprudence of international criminal fora and refers to ICTY case-law and the Statute of the International Criminal Court over 170 times. See Cryer, Robert: Of Custom, Treaties, Scholars and the Gavel: The Influence of the International Criminal Tribunals on the ICRC Customary Law Study, in: Journal of Conflict \& Security Law, Vol. 11, 2006, pp. 239-263, here p. 240.

72 See e.g. Crawford, Emily: Unequal Before the Law: The Case for the Elimination of the Distinction Between International and Non-international Armed Conflicts, in: Leiden Journal of International Law, Vol. 20, 2007, pp. 441-465.

73 DoD Law of War Program, Department of Defense, Directive Number 2311.01E paragraph 4.1, 9 May 2006. "Members of the DoD Components comply with the law of war during all armed conflicts, however such conflicts are characterized, and in all other military operations.".

74 Fleck, Dieter (ed.) The Handbook of Humanitarian Law, Oxford: Oxford University Press, 1999, pp. 48-49.

75 See Canadian Forces Doctrine Manual: The Law of Armed Conflict at the Operational and Tactical Level B-GJ-005-104/FP-021 17-1, paragraph 1702 (13 August 2001) available at http://www.fichl.org/uploads/media/Canadian_LOAC_Manual_ 2001_English.pdf (last accessed: 12 January 2015). "[T] oday a significant number of armed conflicts in which the CF may be involved are non-international in nature. As stated, the law applicable to such conflicts is limited. It is CF policy, however, that the CF will, as a minimum, apply the spirit and principles of the LOAC during all operations other than domestic operations.". 
to the determination of combatant status, clearly rejecting to grant combatant immunity to insurgents.

\section{Universal Application of International Humanitarian Law as an Abuse- Equal Application of Law in Asymmetric Conflicts}

Before the terrorist attacks of 11 September 2001, states usually denied the applicability of international humanitarian law to the fight against terrorism. ${ }^{76}$ Terrorism was generally dealt within the framework of criminal regulation. Still, it seems that the unprecedented magnitude of the 11 September terrorist acts has fundamentally changed the legal framework concerning this issue. President George W. Bush made an oral "declaration of war" on Al Qaeda ${ }^{77}$ and according to the official American doctrine even though the worldwide hostilities with the terrorist group were regulated by jus in bello, the persons participating in terrorist organisations could not enjoy the protection of the Geneva Conventions. ${ }^{78}$

The US Department of Defense evaluated the situation as follows:

The current conflict is not an international war between Nation States, but rather a conflict between a Nation State and a non-governmental organisation. At the same time, the current conflict is not a civil war under Article 3, because it is a conflict of "an international character" rather than an internal armed conflict between parties contending for control over a government or a territory. ${ }^{79}$

76 In ratifying 1977 Geneva Protocol I in 1998, the United Kingdom made a Statement that the term "armed conflict" denotes "a situation which is not constituted by the commission of ordinary crimes including acts of terrorism whether concerted or in isolation." See www.icrc.org (last accessed: 10 January 2015). Still, the UK Government eventually accepted to apply certain international legal standards, even some from the main body of the four 1949 Geneva Conventions. Roberts, Adam: The Laws of War in the War on Terror, in: Israel Yearbook on Human Rights, Vol. 33, 2003, pp. 193-246, here p. 204.

77 Avril McDonald, 'Declarations of War and Belligerent Parties: International Law Governing Hostilities Between States and Transnational Terrorist Networks', Netherlands International Law Review, Vol. 54, 2007, pp. 279-314.

78 Memorandum, President of the United States, to Vice President, et al., subject: Humane Treatment of al Qaeda and Taliban Detainees, 7 February 2002.

79 Memorandum for William J. Haynes II., General Counsel, Department of Defense from John Yoo, Deputy Assistant Attorney General and Robert J. Delabunty, Special Counsel, Re: Application of Treaties and Laws to al Qaeda and Taliban detainees, 9 January 2002. Somewhat similarly the Israeli High Court of Justice ex- 
This global war on terror represents a completely new approach to tackling the problem of terrorism by extending the material scope of application of international humanitarian law. ${ }^{80}$ Even though the existence of a "state of war" could have significance under US domestic law, potentially explaining such categorisation by the US leadership, ${ }^{81}$ the use of legal semantics $^{82}$ was an opportunistic attempt to exploit the normative framework of the law of war. In contrast to earlier fears that the recognition of the existence of a non-international armed conflict could confer status to non-state armed groups, the US administration realised that the norms of armed conflicts - especially those concerning the conduct of hostilities - in an asymmetric conflict inevitably favour the state that possesses a more organised armed force and more advanced technology. ${ }^{83}$

plained that "In today's reality, a terrorist organization is likely to have considerable military capabilities. At times they have military capabilities that exceed those of states. Confrontation with those dangers cannot be restricted within the state and its penal law. Confronting the dangers of terrorism constitutes a part of the international law dealing with armed conflicts of international character." HCJ 769/02 The Public Committee Against Torture in Israel v. The Government of Israel (2006), English translation: http://elyon1.court.gov.il/Files_ENG/02/690/007/ a34/02007690.a34.pdf (last accessed 18 January 2015) paragraph 21.

80 Since 2010, the Obama administration does not speak about global war on terror but armed conflict against al-Qaeda, Taliban and associated forces. But beyond semantics there is no actual change in US policy as the American government follows the global battlefield approach of the Bush administration. See Sterio, Melina: The United States' Use of Drones in the War on Terror: The (Il)legality of Targeted Killings under International Law, in: Case Western Reserve Journal of International Law, Vol. 45, 2012, pp. 197-214, here pp. 201-202.

81 Jinks points out that the categorisation of fight against terrorism as "war" could have significant domestic legal consequences such as the possibility in the United States for the President to assert extraordinary war powers. However, this fact cannot in any way influence the applicability of the regulatory framework of international humanitarian law. Jinks, Derek: The Applicability of the Geneva Conventions to the "Global War on Terror", Vanderbilt Journal of International Law, Vol. 46, 2005-2006, p. 170.

82 Mégret, Frédéric: 'War'? Legal Semantics and the Move to Violence, in: European Journal of International Law, Vol. 13, 2002, pp. 361-400.

83 The US government's legal assessment obviously also directed the decision of the US Supreme Court in the Hamdan case, which seemed to pronounce that the conflict in Afghanistan was of a non-international character. Hamdan v. Rumsfeld, 126 S. Ct. 2749 (2006) at http://www.supremecourtus.gov/opinions/05pdf/05-184. pdf (last accessed: 14 November 2014), p. 67. However, Milanovic rightly points out that it is also possible to read the Hamdan decision as a recognition of the sta- 
In such a situation the recognition of a non-international armed conflict and the concomitant use of international humanitarian law actually has much more severe repercussions for members of a non-state armed group than designating them as criminal and allow human rights law to create limitations for the use of violence. As Dinstein emphasises "in a civil war there is always the built-in distinction between combatants who fight for the central (constitutionally legal) Government and those who rise against it. The latter are viewed as traitors [...]" ${ }^{84}$ Consequently, members of non-state armed groups do not enjoy combatant privileges even if they fully comply with the rules of international humanitarian law and can be prosecuted for mere participation in an armed conflict. On the other hand, they can be targeted (so state forces do not have the obligation to arrest them $)^{85}$ and upon capture possibly detained for an undefined period of time with limited judicial oversight. ${ }^{86}$

This is how the dream of universal application of international humanitarian law has grotesquely been fulfilled: We (the states) now acknow-

tus of Common Article 3 as customary law in all armed conflicts, regardless of the qualification of the situation at hand. Milanovic, Marko: Lessons for Human Rights and Humanitarian Law in the War on Terror: Comparing Hamdan and the Israeli Targeted Killings Case, in International Review of the Red Cross, Vol. 89, 2007, No. 866, pp. 373-393, here p. 377.

84 Dinstein, Yoram: The System of Status Groups in International Humanitarian Law, in: Von Heinegg, Wolff Heintschel/Epping, Volker (eds.): International Humanitarian Law Facing New Challenges, Berlin: Springer-Verlag, 2007, pp. 145156, here pp. $149-150$.

85 There is actually a debate in the legal literature as to the extent to which members of non-state armed groups can be targeted outside the context of actual fighting. The International Committee of the Red Cross proposed a "functional membership approach", meaning that in the absence of an affirmative disengagement members of organised armed groups should be regarded as taking direct part in hostilities, while at the same time unorganised civilians should only be deemed to have lost their civilian immunity and therefore seen as fighters when they are specifically engaged in acts of hostilities. See International Committee of the Red Cross, Interpretative Guideline on the Notion of Direct Participation in Hostilities in International Humanitarian Law. http://www.icrc.org/Web/eng/siteeng0.nsf/htmlall/direct -participation-ihl-article-020609/\$File/direct-participation-guidance-2009-ICRC.p df (last accessed: 18 January 2015) See more in detail Melzer, Nils: Targeted Killing in International Law, Oxford: Oxford University Press, 2008, pp. 324-350.

86 For a thorough perusal of the literature see e.g. Aughey, Sean/Sári, Aurél: Targeting and Detention in NonInternational Armed Conflict: Serdar Mohammed and the Limits of Human Rights Convergence, in: International Law Studies, Vol. 91, 2015, pp. 60-118. 
ledge that you (terrorist/savage etc.) are fighting an armed conflict with us, so give up everything that defended you (such as the lack of distinction from the civilian population) and prepare to die in a fair fight (for instance in a drone strike launched by an operator from another continent)! The ultimate irony is that the progressive jurisprudence of the international criminal fora behind the "humanization" of humanitarian law was guided by a belief that expanding the scope of application of the law of armed conflict will result in ever greater protection. However, the judges seemed to have forgotten that the expansion of international humanitarian law, whose rules were created by a desire to balance military necessity with concerns for humanity, could "crowd out" human rights law, which on the other hand is focusing on the protection of the individual against the state. ${ }^{87}$ And this is how the promise of protection has become the promise of destruction...

\section{Conclusion - The Promise of International Humanitarian Law}

The law of war was originally not created to realise humanitarian aspirations. Even though Lauterpacht forcefully argued that "its purpose is almost entirely humanitarian in the literal sense of the word, namely to prevent or mitigate suffering and, in some cases, to rescue life from the savagery of battle and passion", 88 Jochnick and Normand convincingly contend that the codification of jus in bello was in many respects originally primarily a recognition of systemic factors existing independently of legal regulation. ${ }^{89}$ Humanity in war originally referred to the need to use

87 Hoffmann: The Gentle Humanizer of Humanitarian Law, p. 78.

88 Lauterpacht, Hersch: The Problem of the Revision of the Law of War, in: British Yearbook of International Law, Vol. 29, 1952, pp. 360-382, here pp. 363-364.

89 "War has long been limited largely by factors independent of law. For complex military, political, and economic reasons, belligerents tend to use the minimal force necessary to achieve their political objectives. Force that goes beyond that - gratuitous violence - wastes resources, provokes retaliation, invites moral condemnation, and impedes post-war relations with the enemy nation." Jochnick, Chris/Normand, Roger: The Legitimation of Violence: Critical History of the Laws of War, in: Harvard International Law Journal, Vol. 35, 1994, pp. 49-95, here pp. 53-54. 
any necessary means to reduce the period of fighting. ${ }^{90}$ This explains how the German Imperial Chancellor could address the Reichstag in March 1916 with the following words:

Every means that is calculated to shorten the war constitutes the most humane policy to follow. When the most ruthless measures are considered best calculated to lead us to victory, and a swift victory [...] they must be employed. ${ }^{91}$

Today, however, international humanitarian law is no longer dependent on reciprocity, the si omnes (general application) clauses no longer vitiate the application of humanitarian treaties and the rules concerning the protection of the victims of war are characterised by strict, non-derogable prohibitions. Yet, the regulation of the conduct of hostilities, such as targeting rules employing vaguely worded principles still creates a playing field which enables powerful states to use the normative framework to their own advantage and could hardly deserve to be called humanitarian. ${ }^{92}$ From a sociological point of view, this is exacerbated by the fact that due to the complex and technical regulatory framework of international humanitarian law general international lawyers usually tended to neglect this field. O'Donoghue explains that:

This specialisation is in part driven by the dominance of certain forms of legal expertise, in particular, the military and the International Committee of the Red Cross (ICRC). The military, for obvious reasons, has a particular perspective and focus on IHL and further, has the resources necessary to command a complete understanding of all its rules. Similarly, the ICRC, with its competence driven by IHL treaty law, maintains a complete expertise. While military and ICRC opinion may not always correlate, their knowledge and competence, which extends to understanding all the rules of IHL, makes it

90 The celebrated Lieber Code, for instance, pronounced in paragraph 15 that "the more vigorously wars are pursued, the better it is for humanity. Sharp wars are brief." General Order No. 100, 24 April 1863, Official Records, US War Department, The War of the Rebellion: A Compilation of the Official Records of the Union and Confederate Armies, Washington, D.C.: Government Printing Office, 1899, Series III, Vol. 3, pp. 148-164, here p. 152.

91 Cited in Garner, James Wilford: Studies in Government and International Law, Illinois: The University of Illinois Press, 1943, p. 271.

92 Solis aptly points out that "[A] few scholars argue that both "law of war" and "law of armed conflict", are passé terms, replaced in the eyes of some internationalists by "international humanitarian law", passing over the irony how a body of law defining how noncombatants may lawfully be killed (i.e., collateral damage) is "humanitarian"." Solis, The Law of Armed Conflict, p. 22. 
Tamás Hoffmann

difficult for those outside this realm to compete without being dismissed as ignorant of the entirety of the law and therefore not competent to comment. ${ }^{93}$

Nevertheless, international humanitarian law is not beyond redemption. The general principles that until today served as a means to further state interest can become a site for contestation and used to restrict violence in armed conflict. ${ }^{94}$ If general international lawyers discover international humanitarian law and start to challenge old orthodoxies, maybe the old dream of equal protection in warfare will finally come to fruition.

93 O’Donoghue, Aoife: Splendid Isolation: International Humanitarian Law, Legal Theory and the International Legal Order, in: Yearbook of International Humanitarian Law, Vol. 14, 2011, pp. 107-131, here p. 109.

94 For a recent doctrinal attempt to interpret international humanitarian law as restricting the right to freely target combatants see Goodman, Ryan: The Power to Kill or Capture Enemy Combatants, in: European Journal of International Law, Vol. 24, 2013, No. 3, pp. 819-853. 